\title{
Prevalences of leg and chest abnormalities in four South African schoolchild populations with special reference to vitamin D status
}

\author{
BARBARA D. RICHARDSON \\ D.Sc. \\ Alexander R. P. Walker \\ D.Sc.
}

\author{
South African Medical Research Council Human Biochemistry Research Unit, \\ South African Institute for Medical Research, Johannesburg, South Africa
}

\begin{abstract}
Summary
Prevalences of bowing and knock knee, measured at a standard stance, have been obtained on Negro, Coloured, Indian and Caucasian schoolchildren aged 7, 12, and 16-17 years. These two abnormalities were unexpectedly common, affecting about one-fifth and one-third of all children respectively. Ranges of prevalences of chest abnormalities were-Harrison's sulcus, $0-5 \%$, and pigeon chest, 0-2\%. Prevalence of bowing increased with age. That of knock knee was little affected by age, but increased markedly with body mass. There was no age trend with prevalences of chest abnormalities.
\end{abstract}

Prevalences appeared unrelated to vitamin D intake. As to sunshine, the annual mean for the Transvaal is $8.4 \mathrm{hr}$ daily. Results from radiological, skin pigmentation, and biochemical studies were non-contributory. Since a primary deficiency of vitamin $D$ is evidently not the causal factor, one explanation is that a secondary deficiency is involved, arising from an impairment in metabolic availability. Further, a proportion of leg abnormalities may be physiological variants; moreover, it cannot be excluded that unknown factors may bear, or share, in responsibility.

Elucidation may be forthcoming by investigating the interrelationship between vitamin $D$ status and frequency of leg abnormalities during and after puberty; in addition, results of serial studies of prevalences of abnormalities from birth to post-adolescence would be illuminating.

\section{Introduction}

In the course of a variety of studies in the field it was noted that bowing and knock knee were common in schoolchildren. Outwardly, this was puzzling since there is an abundant supply of sunshine in South Africa; for example, the Transvaal has an annual mean of $8.4 \mathrm{hr}$ daily (Weather Bureau, 1968). It is therefore unlikely that vitamin $\mathrm{D}$, derived from

Correspondence: Dr B. D. Richardson, South African Medical Research Council Human Biochemistry Research Unit, South African Institute for Medical Research, P.O. Box 1038, Johannesburg 2000, South Africa. solar exposure, is inadequate. Yet studies at hospitals and clinics have revealed rickets to be common in Negro infants and young children in large centres of population (Feldman, 1950; Dancaster and Jackson, 1962; Taitz, 1962; Taitz and de Lacy, 1962; Robertson, 1969; Joffe et al., 1972). In Cape Town, Robertson (1969) reported the disease in Negro, Coloured and Caucasian infants.

In the literature, both bowing and knock knee are usually considered to be rachitic in origin, although none have maintained that all of such leg abnormalities are due to this deficiency disease. Some workers (Holt et al., 1954; Sherman, 1960) have regarded these leg abnormalities in young children as physiological variants, which could straighten once the child reached 6-8 years. Early workers recognized that the disease was not limited to the period of infancy. Glisson (1650), who established rickets as a clinical entity, is remembered for his description of 'the older child, dwarfed, distorted and bow-legged', a condition now known as 'Glissonian rickets'. Moreover, Parker, in 1888, from his observations on children from infancy to adolescence concluded that 'rickets was a condition which might last from birth up to the fifteenth or seventeenth year of life'.

So far as we are aware no data are available on prevalences of bowing and knock knee in representative populations, and no attempt appears to have been made to quantify degrees of abnormality. In seeking to throw light on the occurrence and causation of abnormalities, observations have been carried out on four ethnic groups of schoolchildren, namely, Negro, Coloured (Eur-African-Malay), Indian, and Caucasian. Schoolchild populations were chosen because of their ready availability; preschool populations will be studied later. Additionally, prevalences of abnormalities of the chest, usually attributed to rickets, including Harrison's sulcus and pigeon chest, were obtained. In seeking to elucidate causal factors, dietary, radiological, and biochemical studies were carried out, as well as investigations on skin pigmentation. 


\section{Material and methods}

\section{Subjects}

Investigations were made on pupils of 7,12 , and 16-17 years, representing pre-pubertal, pubertal, and post-pubertal groups. All urban pupils lived in Johannesburg or surrounding residential areas. Rural Negroes were from areas in eastern and north-eastern Transvaal.

\section{Surveys for leg abnormalities}

Data on numbers and sex of groups of pupils examined for bowing and knock knee are detailed in Table 1.

\section{Anthropometric and chest examinations}

Only at selected schools were all pupils in the age groups mentioned examined. These included (1) Negro rural group, 526 (268 boys, 258 girls); Negro urban group, 380 (187 boys, 193 girls); (2) Coloured urban group, 452 (243 boys, 209 girls); (3) Indian urban group, 339 (166 boys, 173 girls), ; (4) Caucasian urban group, 432 (232 boys, 200 girls).

\section{Dietary survey}

In the Transvaal, with the help of domestic science teachers, 168 girls of 16-17 years completed the dietary questionnaire forms; thirty were Negro, forty-four Coloured, fifty-six Indian, and thirtyeight Caucasian. In the Cape Town area, with the help of parents, 151 Coloured girls and boys of 12 years completed dietary questionnaire forms; fifty-eight were from high fish-eating communities, residing in the coastal fishing villages of Hout and Kalk Bays, situated 20 and $37 \mathrm{~km}$ south of Cape Town respectively; and ninety-three were from a community eating less fish at Elsies River, situated inland, $35 \mathrm{~km}$ north of Cape Town.

\section{Radiological studies}

Anterior-posterior X-rays of the left hand and wrist were taken of ninety-six Negro girls and boys aged 16-17 years, resident at Soweto, Johannesburg. Of these, which included approximately equal numbers of each sex, thirty-two had marked bowing, thirty-two marked knock knee, and thirty-two straight legs.

\section{Skin pigmentation determined by reflectance photometry}

Skin reflectance was measured on the same pupils examined for radiological studies.

\section{Biochemical studies}

Blood samples were collected from 106 urban Negro girls and boys aged 16-17 years. This group also included those who participated in the radiological and skin pigmentation studies. Thirty-five had marked bowing, thirty-seven marked knock knee, and thirty-four straight legs. Samples were also collected from 105 Coloured children (girls and boys) of 12 years, from high and low fish-eating communities in the Cape Province. Fifty-one pupils were from high fish-eating areas, of whom thirteen had bowing, nineteen knock knee, and eighteen straight legs; fifty-four were pupils from the community eating less fish, of whom nineteen had bowing, sixteen knock knee, and nineteen straight legs.

\section{Methods}

Measurement of extent of bow leg and knock knee

When making measurements, subjects stood either on a laboratory stool, form or flat chair. A standard stance was assumed, namely, feet parallel, ankles touching when possible, and knees pressed back comfortably with no tension in the femoral muscle groups. The buttocks were not protruded so that the subject stood in an easily maintained, naturally upright position. For bowing, the desirable measurement is the distance between the medial femoral

TABLE 1. Age and sex structure of schoolchild population groups used for studies of prevalences of bowing and knock knee

\begin{tabular}{|c|c|c|c|c|c|c|c|c|c|c|c|c|}
\hline \multirow[b]{2}{*}{ Group } & \multicolumn{3}{|c|}{7 years } & \multicolumn{3}{|c|}{12 years } & \multicolumn{3}{|c|}{$16-17$ years } & \multicolumn{3}{|c|}{ Total } \\
\hline & $\mathbf{M}$ & $\mathbf{F}$ & $\mathbf{T}$ & $\mathbf{M}$ & $\mathbf{F}$ & $\mathbf{T}$ & $\mathbf{M}$ & $\mathbf{F}$ & $\mathbf{T}$ & $\mathbf{M}$ & $\mathbf{F}$ & $\mathbf{T}$ \\
\hline \multicolumn{13}{|l|}{ Negro } \\
\hline $\begin{array}{l}\text { Rural } \\
\text { Urban }\end{array}$ & $\begin{array}{r}253 \\
74\end{array}$ & $\begin{array}{r}260 \\
78\end{array}$ & $\begin{array}{l}513 \\
152\end{array}$ & $\begin{array}{r}251 \\
78\end{array}$ & $\begin{array}{r}256 \\
70\end{array}$ & $\begin{array}{l}507 \\
148\end{array}$ & $\begin{array}{l}291 \\
284\end{array}$ & $\begin{array}{l}315 \\
413\end{array}$ & $\begin{array}{l}606 \\
697\end{array}$ & $\begin{array}{l}795 \\
436\end{array}$ & $\begin{array}{l}831 \\
561\end{array}$ & $\begin{array}{r}1626 \\
997\end{array}$ \\
\hline Coloured & & & & & & & & & & & & \\
\hline Urban & 86 & 83 & 169 & 108 & 77 & 185 & 198 & 128 & 326 & 392 & 288 & 680 \\
\hline Indian & & & & & & & & & & & & \\
\hline $\begin{array}{c}\text { Urban } \\
\text { Caucasian }\end{array}$ & 111 & 134 & 245 & 131 & 115 & 246 & 304 & 147 & 451 & 546 & 396 & 942 \\
\hline Urban & 194 & 159 & 353 & 230 & 230 & 460 & 223 & 169 & 392 & 647 & 558 & 1205 \\
\hline Total & 718 & 714 & 1432 & 798 & 748 & 1546 & 1300 & 1172 & 2472 & 2816 & 2634 & 5450 \\
\hline
\end{tabular}


condyles. However, for practical purposes, the actual measurement made was at mid-patella (which corresponds approximately with the medial condyles, provided patellae are allowed to assume their relaxed position and are not drawn up by femoral muscles). As to knock knee, when knees overlocked and there was obvious difficulty in apposition of ankles, the feet were separated and placed parallel, at a distance where knees just touched comfortably when pressed back, but were not under strain. The distance between the medial tibial malleoli was measured. When legs were straight, both knees and ankles were in apposition and there were no gaps.

At the commencement a sliding caliper* was used. Later cardboard rectangles, $8 \mathrm{~cm}$ long, cut to specific widths, were employed. Rectangles were introduced into the gaps at knee or ankle and the appropriate widths noted. Those used were $1.5 \mathrm{~cm}$, $2.5 \mathrm{~cm}, 3.0 \mathrm{~cm}$, and $3.5 \mathrm{~cm}$. For the present investigation, data are given of numbers whose gaps were $2.5 \mathrm{~cm}$ or more; persons with such gaps were regarded as exhibiting obvious abnormalities.

It must be noted that unless extreme care was taken in positioning correctly, prevalence figures could vary widely. Regarding repeatability, measurements in 100 consecutive pupils, by two observers, gave percentage differences in readings for gaps of $2.5 \mathrm{~cm}$ or more, at knee as $10 \%$, and at ankle $7.5 \%$. Differences were due almost exclusively to the positioning of the legs, before measurement.

\section{Anthropometric and chest examinations}

Height and mass. Measurements of height (in centimetres) and mass (in kilograms) were made on all pupils.

Chest abnormalities. At selected schools, examinations for bone deformities of the chest were made by observation and palpation, when applicable. Pupils stood upright with body mass evenly distributed on both feet. Note was made of the presence of skeletal abnormalities affecting the chest wall, namely, Harrison's sulcus, pigeon chest, asymmetry of chest, funnel-shaped sternum, and narrow fiat chest.

Obesity was defined as a body mass of $20 \%$ or more, greater than the fiftieth percentile for age and sex (Craddock, 1969). Pupils were assessed for obesity according to Iowa growth standards (Jackson and Kelly, 1945).

\section{Dietary survey}

In the Transvaal, dietary questionnaire forms, which provided a list of common foods containing vitamin $D$ such as fish, animal and dairy products, were completed by senior girls of 16-17 years, with the aid of domestic science teachers. Pupils gave the

\footnotetext{
* GPM Anthropological Instruments, Siber Hegner and
} Co. Ltd, 14 Talstrasse, 8022 Zurich, Switzerland. number of medium-sized portions of meat or fish, approximating a half slice of bread $1 \mathrm{~cm}$ thick, also the amounts of dairy produce, etc. consumed per week. Quantities, in grams, were estimated and daily amounts of vitamin $\mathrm{D} / 100 \mathrm{~g}$ calculated using the food tables of Avioli and Haddad (1973).

In the Cape Town area, the questionnaire, completed by Coloured pupils of 12 years, included foodstuffs mentioned above, also a more detailed list of different varieties of fish caught seasonally in Cape waters, which are freely eaten by fishermen and their families. These varieties included 'fatty' fish, namely, yellowtail, harders (mullet), Cape salmon, pilchard, mackerel, etc. which contain greater amounts of vitamin D (McLaughlin, 1973) than the non-fatty varieties, such as hake (stock fish), which contain negligible amounts (Fox, 1966). The daily intake of vitamin $\mathrm{D}$ was calculated as before.

\section{Radiological studies}

$\mathrm{X}$-ray plates were examined for the presence of active rickets by a specialist radiologist, Dr J. I. Levy, of the Department of Radiology, Medical School, University of the Witwatersrand. Cortical thickness of the second metacarpal was measured, and cortical index calculated (Barnett and Nordin, 1960).

\section{Skin pigmentation studies}

Using a portable EEL Reflectance Spectrophotometer, measurements at wavelengths of 425 and $685 \mathrm{~nm}$, i.e. filters 601 and 609, were made (1) on the medial aspect of the left upper arm, an area little exposed to solar radiation and (2) on the forehead, an area of greatest exposure to solar radiation (Weiner et al., 1964).

\section{Biochemical studies}

Serum alkaline phosphatase, calcium and inorganic phosphate were determined on the blood samples collected. Alkaline phosphatase was measured using the Ames/BMI Blood Analyser and the modified method of Bessey-Lowry-Brock (Ames Company Technical Manual, 1970). Serum calcium and inorganic phosphate were measured on the Technicon Auto Analyser II, using the methods of Gitelman (1967) and Hurst (1967) respectively. Serum was kept deep frozen $\left(-10^{\circ} \mathrm{C}\right)$ until required for the latter determinations.

\section{Results}

\section{Prevalences of bowing and knock knee}

Prevalences of bowing and knock knee, with gaps of $2.5 \mathrm{~cm}$ or more, are given in Table 2 .

It will be seen in the respective sex-age groups that there were no outstanding differences in prevalences of bowing and of knock knee in the four ethnic 
TABle 2. Prevalences of bowing and knock knee of $2.5 \mathrm{~cm}$ or more, according to age, sex, and ethnic group

\begin{tabular}{|c|c|c|c|c|c|c|c|}
\hline \multirow[b]{2}{*}{$\begin{array}{c}\text { Leg } \\
\text { abnormality }\end{array}$} & \multirow[b]{2}{*}{ Group } & \multicolumn{2}{|c|}{7 years } & \multicolumn{2}{|c|}{12 years } & \multicolumn{2}{|c|}{$16-17$ years } \\
\hline & & $\begin{array}{c}\text { Male } \\
(\%)\end{array}$ & $\begin{array}{c}\text { Female } \\
(\%)\end{array}$ & $\begin{array}{c}\text { Male } \\
(\%)\end{array}$ & $\begin{array}{c}\text { Female } \\
(\%)\end{array}$ & $\begin{array}{c}\text { Male } \\
(\%)\end{array}$ & $\begin{array}{c}\text { Female } \\
(\%)\end{array}$ \\
\hline \multicolumn{8}{|l|}{ Bowing } \\
\hline & $\begin{array}{l}\text { Negro } \\
\text { Rural }\end{array}$ & $4 \cdot 5$ & $10 \cdot 5$ & $21 \cdot 0$ & 22.4 & 24.7 & \\
\hline & Urban & $6 \cdot 8$ & 8.9 & 9.0 & 10.0 & 26.4 & $\begin{array}{l}22 \cdot 3 \\
13 \cdot 3\end{array}$ \\
\hline & Coloured & & & & & & \\
\hline & $\begin{array}{l}\text { Urban } \\
\text { Indian }\end{array}$ & $8 \cdot 2$ & $6 \cdot 0$ & $8 \cdot 3$ & $17 \cdot 5$ & $20 \cdot 2$ & $10 \cdot 0$ \\
\hline & $\begin{array}{c}\text { Urban } \\
\text { Caucasian }\end{array}$ & $9 \cdot 9$ & $8 \cdot 2$ & $6 \cdot 1$ & $8 \cdot 7$ & $19 \cdot 4$ & $7 \cdot 5$ \\
\hline & Urban & $5 \cdot 7$ & $6 \cdot 6$ & $15 \cdot 0$ & $17 \cdot 4$ & $22 \cdot 9$ & $13 \cdot 6$ \\
\hline \multirow{7}{*}{ Knock knee } & Negro & & & & & & \\
\hline & Rural & $14 \cdot 2$ & $12 \cdot 7$ & $14 \cdot 5$ & $13 \cdot 1$ & $16 \cdot 6$ & $26 \cdot 2$ \\
\hline & Urban & $29 \cdot 7$ & $32 \cdot 0$ & $32 \cdot 0$ & $42 \cdot 9$ & $16 \cdot 9$ & $29 \cdot 9$ \\
\hline & Coloured & & & & & & \\
\hline & $\begin{array}{l}\text { Urban } \\
\text { Indian }\end{array}$ & $26 \cdot 2$ & $25 \cdot 9$ & $19 \cdot 9$ & $28 \cdot 5$ & $17 \cdot 1$ & $28 \cdot 8$ \\
\hline & $\begin{array}{c}\text { Urban } \\
\text { Caucasian }\end{array}$ & $17 \cdot 1$ & $28 \cdot 3$ & $17 \cdot 4$ & $20 \cdot 8$ & $12 \cdot 3$ & $27 \cdot 8$ \\
\hline & Urban & 20.9 & $24 \cdot 7$ & $21 \cdot 3$ & $23 \cdot 0$ & $14 \cdot 6$ & $22 \cdot 7$ \\
\hline
\end{tabular}

groups. Within particular ethnic-sex-age groups, ranges of prevalences of abnormalities in the constituent groups (from different schools) were occasionally wide. There were no marked differences in data on country compared with town dwellers.

Regarding bowing, a finding of major interest was the increase in prevalence with age. An exception was Indian girls, among whom respective prevalences at 7,12 , and $16-17$ years were $8 \cdot 2 \%, 8.7 \%$ and $7.5 \%$. At 12 years, girls generally had higher prevalences of bowing than did boys; this may be related to the earlier growth spurt of girls.

From more extensive investigations on several total school populations, all ages from 6 to 14 years, which included the three age groups described in this paper, it appeared that there was a definite increase in prevalence of bowing during the active growth phase of puberty. This growth phase occurred earlier in Caucasians than in non-Caucasians.

There was no rise in prevalence of knock knee with age. The abnormality was usually commoner in girls than in boys. There was a tendency with boys, although not with girls, for prevalences to decrease after 12 years.

Table 3 shows the percentages of obese children with bowing, knock knee, and with straight legs. The percentages exhibiting obesity at the three age periods were Negroes, $1,2 \cdot 5,6$; Coloureds, 3, 6, 6; Indians, 3·5, 5·5, 2; Caucasians, 8, 16.5, 18.

TABLE 3. Percentages of pupils exhibiting bowing, straight legs, and knock knee who are obese

\begin{tabular}{|c|c|c|c|c|c|c|c|}
\hline \multirow[b]{2}{*}{$\begin{array}{c}\text { Age } \\
\text { (years) }\end{array}$} & \multirow[b]{2}{*}{ Group } & \multicolumn{3}{|c|}{ Males } & \multicolumn{3}{|c|}{ Females } \\
\hline & & $\begin{array}{c}\text { Bowing } \\
(\%)\end{array}$ & $\begin{array}{c}\text { Straight } \\
\text { legs } \\
(\%)\end{array}$ & $\begin{array}{c}\text { Knock } \\
\text { knee } \\
(\%)\end{array}$ & $\begin{array}{c}\text { Bowing } \\
(\%)\end{array}$ & $\begin{array}{c}\text { Straight } \\
\text { legs } \\
(\% \%)\end{array}$ & $\begin{array}{c}\text { Knock } \\
\text { knee } \\
(\%)\end{array}$ \\
\hline 7 & $\begin{array}{l}\text { Negro } \\
\text { Coloured } \\
\text { Indian } \\
\text { Caucasian }\end{array}$ & $\begin{array}{l}0.0 \\
0.0 \\
0.0 \\
6.7\end{array}$ & $\begin{array}{l}0.0 \\
0.0 \\
0.0 \\
6.7\end{array}$ & $\begin{array}{r}1 \cdot 7 \\
13 \cdot 4 \\
10 \cdot 6 \\
12 \cdot 1\end{array}$ & $\begin{array}{l}0.0 \\
0.0 \\
0.0 \\
0.0\end{array}$ & $\begin{array}{l}0.0 \\
0.0 \\
0.0 \\
4.5\end{array}$ & $\begin{array}{r}1 \cdot 7 \\
9 \cdot 3 \\
13 \cdot 2 \\
16 \cdot 9\end{array}$ \\
\hline 12 & $\begin{array}{l}\text { Negro } \\
\text { Coloured } \\
\text { Indian } \\
\text { Caucasian }\end{array}$ & $\begin{array}{r}1 \cdot 7 \\
11 \cdot 1 \\
0 \cdot 0 \\
7 \cdot 6\end{array}$ & $\begin{array}{l}0.0 \\
0.0 \\
1 \cdot 5 \\
9.5\end{array}$ & $\begin{array}{r}1.6 \\
18.6 \\
30.4 \\
45 \cdot 5\end{array}$ & $\begin{array}{r}1.5 \\
14.9 \\
0.0 \\
14.9\end{array}$ & $\begin{array}{r}0.0 \\
0.0 \\
2.4 \\
11 \cdot 8\end{array}$ & $\begin{array}{r}4 \cdot 7 \\
9 \cdot 1 \\
20 \cdot 7 \\
42 \cdot 1\end{array}$ \\
\hline $16-17$ & $\begin{array}{l}\text { Negro } \\
\text { Coloured } \\
\text { Indian } \\
\text { Caucasian }\end{array}$ & $\begin{array}{r}0 \cdot 7 \\
2 \cdot 5 \\
1 \cdot 5 \\
11 \cdot 8\end{array}$ & $\begin{array}{r}0.0 \\
0.0 \\
0.0 \\
14.8\end{array}$ & $\begin{array}{r}1 \cdot 3 \\
46 \cdot 1 \\
14 \cdot 3 \\
25 \cdot 4\end{array}$ & $\begin{array}{r}1.6 \\
7.7 \\
0.0 \\
21.7\end{array}$ & $\begin{array}{l}1 \cdot 2 \\
7.0 \\
0.0 \\
8 \cdot 6\end{array}$ & $\begin{array}{r}25 \cdot 3 \\
18 \cdot 9 \\
9 \cdot 7 \\
54 \cdot 5\end{array}$ \\
\hline
\end{tabular}


Knock knee was commoner in obese compared with non-obese subjects, and, as would be expected, prevalences were higher in girls than in boys.

\section{Prevalences of chest abnormalities}

In Table 4, prevalences of chest abnormalities are given for combined groups of children exhibiting bowing, knock knee, or straight legs, since there were no outstanding ethnic group, sex, or age differences in prevalences.

Prevalences of chest abnormalities did not correlate with prevalences of leg abnormalities.

\section{Influencing factors}

\section{Vitamin D status and skeletal abnormalities}

In the Transvaal, calculations revealed that the mean daily intakes of vitamin D were low, namely, 202, 210, 159 and 174 iu for Negroes, Coloureds, Indians, and Caucasians respectively. Prevalences of bowing and knock knee in Cape Town Coloured pupils in the high and lower fish consuming groups are given in Table 5 .

The high fish-eating Coloured group had a mean daily intake of 311 iu of vitamin D. Their range of intake was large, from 39 to $1078 \mathrm{iu} /$ day. Some of the families were very poor. Mean intakes of vitamin $D$ in the upper and lower quartiles were 569 and $113 \mathrm{iu} /$ day. Corresponding data among the lower fish-eating group at Elsies River were 354 and 119; the mean was 224 iu/day.

In spite of the higher vitamin D status of the high fish-eating group of pupils, prevalences of bowing, knock knee, and straight legs were similar to those of (1) groups of pupils at Elsies River, where less fish was consumed, also (2) the group eating still less fish, namely, the Coloured children studied in Johannesburg. Thus, the higher intake of vitamin D was not associated with lower prevalences of leg or of chest abnormalities. On the other hand, there was a lesser exposure to solar radiation in Cape Town area, as the mean annual sunshine was $6.7 \mathrm{hr}$ daily, compared with that of the Transvaal, $8.5 \mathrm{hr}$ (Weather Bureau, 1968). The lesser amount of sunshine in the Cape Town area, probably compensated for in the high fish-eating group, did not apparently influence prevalences of leg abnormalities.

\section{$X$-rays of wrists and hands}

No evidence of active rickets was detected in bones of the wrist and hand of Negro pupils of 16-17

TABLE 4. Prevalences of chest abnormalities in schoolchildren* with bowing, knock knee, or straight legs

\begin{tabular}{|c|c|c|c|c|c|c|c|}
\hline $\begin{array}{c}\text { Leg } \\
\text { abnormality }\end{array}$ & $\begin{array}{c}\text { Age } \\
\text { (years) }\end{array}$ & $\begin{array}{l}\text { No. of } \\
\text { subjects }\end{array}$ & $\begin{array}{c}\text { Harrison's } \\
\text { sulcus } \\
(\%)\end{array}$ & $\begin{array}{c}\text { Flaring } \\
\text { of ribs } \\
(\%)\end{array}$ & $\begin{array}{c}\text { Pigeon chest } \\
(\%)\end{array}$ & $\begin{array}{l}\text { Funnel-shaped } \\
\text { sternum } \\
(\%)\end{array}$ & $\begin{array}{c}\text { Narrow, } \\
\text { flat chest } \\
(\%)\end{array}$ \\
\hline Bowing & $\begin{array}{c}7 \\
12 \\
16-17\end{array}$ & $\begin{array}{l}117 \\
166 \\
164\end{array}$ & $\begin{array}{l}1 \cdot 7 \\
1 \cdot 2 \\
3 \cdot 0\end{array}$ & $\begin{array}{l}7 \cdot 7 \\
6 \cdot 6 \\
9 \cdot 8\end{array}$ & $\begin{array}{l}0.0 \\
1 \cdot 2 \\
0.0\end{array}$ & $\begin{array}{r}0.0 \\
1 \cdot 8 \\
10 \cdot 3\end{array}$ & $\begin{array}{l}17 \cdot 1 \\
17 \cdot 5 \\
46 \cdot 8\end{array}$ \\
\hline Knock knee & $\begin{array}{c}7 \\
12 \\
16-17\end{array}$ & $\begin{array}{l}183 \\
156 \\
108\end{array}$ & $\begin{array}{l}1 \cdot 1 \\
1 \cdot 3 \\
0 \cdot 9\end{array}$ & $\begin{array}{r}12 \cdot 1 \\
6 \cdot 4 \\
5 \cdot 5\end{array}$ & $\begin{array}{l}0.0 \\
0.0 \\
0.9\end{array}$ & $\begin{array}{l}4 \cdot 3 \\
1 \cdot 9 \\
3 \cdot 7\end{array}$ & $\begin{array}{r}6 \cdot 0 \\
8 \cdot 3 \\
12 \cdot 1\end{array}$ \\
\hline Straight legs & $\begin{array}{c}7 \\
12 \\
16-17\end{array}$ & $\begin{array}{l}340 \\
256 \\
177\end{array}$ & $\begin{array}{l}2 \cdot 3 \\
2 \cdot 7 \\
2 \cdot 2\end{array}$ & $\begin{array}{r}13 \cdot 5 \\
7 \cdot 8 \\
7 \cdot 9\end{array}$ & $\begin{array}{l}0.8 \\
0.0 \\
0.0\end{array}$ & $\begin{array}{l}2 \cdot 3 \\
3 \cdot 9 \\
2 \cdot 2\end{array}$ & $\begin{array}{l}16 \cdot 7 \\
16 \cdot 7 \\
23 \cdot 6\end{array}$ \\
\hline
\end{tabular}

* All four ethnic groups of schoolchildren combined.

TABLE 5. Prevalences of bowing and knock knee in Coloured pupils consuming high and low quantities of fish, according to age and sex

\begin{tabular}{|c|c|c|c|c|c|c|c|c|c|c|}
\hline \multirow[b]{2}{*}{$\begin{array}{c}\text { Age } \\
\text { (years) }\end{array}$} & \multirow[b]{2}{*}{ Sex } & \multicolumn{3}{|c|}{$\begin{array}{c}\text { High fish-eaters } \\
\text { (Hout and Kalk Bays, } \\
\text { Cape Town) }\end{array}$} & \multicolumn{3}{|c|}{$\begin{array}{l}\text { Lower fish-eaters } \\
\text { (Elsies River, } \\
\text { Cape Town) }\end{array}$} & \multicolumn{3}{|c|}{$\begin{array}{l}\text { Lowest fish-eaters } \\
\text { (Coronationville, } \\
\text { Johannesburg) }\end{array}$} \\
\hline & & No. & $\begin{array}{c}\text { Bowing } \\
(\%)\end{array}$ & $\begin{array}{c}\text { Knock } \\
\text { knee } \\
(\%)\end{array}$ & No. & $\begin{array}{c}\text { Bowing } \\
(\%)\end{array}$ & $\begin{array}{c}\text { Knock } \\
\text { knee } \\
(\%)\end{array}$ & No. & $\begin{array}{c}\text { Bowing } \\
(\%)\end{array}$ & $\begin{array}{c}\text { Knock } \\
\text { knee } \\
(\%)\end{array}$ \\
\hline 7 & $\begin{array}{l}\mathbf{M} \\
\mathbf{F}\end{array}$ & $\begin{array}{l}44 \\
56\end{array}$ & $\begin{array}{l}0.0 \\
5 \cdot 4\end{array}$ & $\begin{array}{l}38 \cdot 6 \\
33 \cdot 8\end{array}$ & $\begin{array}{l}52 \\
48\end{array}$ & $\begin{array}{l}3 \cdot 8 \\
0 \cdot 0\end{array}$ & $\begin{array}{l}32 \cdot 6 \\
37 \cdot 5\end{array}$ & $\begin{array}{l}86 \\
83\end{array}$ & $\begin{array}{l}8 \cdot 2 \\
6 \cdot 0\end{array}$ & $\begin{array}{l}26 \cdot 2 \\
25 \cdot 9\end{array}$ \\
\hline 12 & $\begin{array}{l}\mathbf{M} \\
\mathbf{F}\end{array}$ & $\begin{array}{l}50 \\
36\end{array}$ & $\begin{array}{r}10 \cdot 0 \\
8 \cdot 3\end{array}$ & $\begin{array}{l}28 \cdot 0 \\
52 \cdot 8\end{array}$ & $\begin{array}{l}43 \\
55\end{array}$ & $\begin{array}{l}6.9 \\
1.8\end{array}$ & $\begin{array}{l}25 \cdot 6 \\
36 \cdot 4\end{array}$ & $\begin{array}{r}108 \\
77\end{array}$ & $\begin{array}{r}8 \cdot 3 \\
17 \cdot 5\end{array}$ & $\begin{array}{l}19 \cdot 9 \\
28 \cdot 5\end{array}$ \\
\hline $16-17$ & $\begin{array}{l}\mathbf{M} \\
\mathbf{F}\end{array}$ & $\begin{array}{l}55 \\
60\end{array}$ & $\begin{array}{l}18 \cdot 2 \\
16 \cdot 8\end{array}$ & $\begin{array}{l}12 \cdot 7 \\
39 \cdot 1\end{array}$ & $\begin{array}{l}113 \\
105\end{array}$ & $\begin{array}{r}13 \cdot 2 \\
9 \cdot 5\end{array}$ & $\begin{array}{l}22 \cdot 1 \\
34 \cdot 2\end{array}$ & $\begin{array}{l}198 \\
128\end{array}$ & $\begin{array}{l}20 \cdot 2 \\
10 \cdot 0\end{array}$ & $\begin{array}{l}17 \cdot 1 \\
28 \cdot 8\end{array}$ \\
\hline
\end{tabular}


years in groups with marked bowing, knock knee, or those with straight legs. In these three groups data on mean cortical thickness and cortical index of second metacarpal were similar.

\section{Skin pigmentation}

No marked differences in skin colour prevailed between Negro pupils of 16-17 years, who had marked bowing, knock knee, or straight legs.

\section{Biochemical studies}

In groups of Negro pupils of 16-17 years and Coloured pupils of 12 years, no significant differences $(P>0.05)$ prevailed in mean values for serum alkaline phosphatase, calcium or inorganic phosphate, in respect of groups of subjects with marked bowing, knock knee, or straight legs.

\section{Discussion}

\section{Prevalences of leg and chest abnormalities}

Briefly it was found that (1) frequencies of bowing and knock knee were high, (2) frequencies of bowing and of knock knee did not differ markedly in the four ethnic groups studied, (3) frequency of bowing, but not knock knee, rose with age. Attention was drawn to these three points in a letter published in the Lancet (Richardson and Walker, 1973), (4) frequency of knock knee was higher in obese compared with non-obese children, (5) rural-urban frequencies were much the same, (6) neither variations in sunshine nor differences in skin pigmentation appeared to be important, and there was no correlation between leg and chest abnormalities.

\section{The role of dietary vitamin $D$ in the pathogenesis of leg abnormalities}

The low intakes of vitamin D among South African children were similar to data reported elsewhere. In Pakistani children in Glasgow, Ford et al. (1972) reported daily intakes of $189 \mathrm{iu}$; Scottish Caucasian children probably ingest less than 100 iu (Arneil, 1967; Richards, Sweet and Arneil, 1968).

Could the leg abnormalities in South African children be due to low or marginal intakes of vitamin $\mathbf{D}$ ? This is most unlikely since, despite the greater vitamin $D$ intakes of the high fish-eating Coloured children in Cape Town, they had prevalences of bowing and knock knee similar to those who had lower intakes. These findings were discussed briefly in a letter published in the New England Journal of Medicine (Richardson and Walker, 1974).

Our observations are analogous to those made in Israel by Garti and Winter (1964) who reported that ' 1000 schoolboys over the age of 10 were examined for the presence of permanent skeletal deformities of rachitic origin. 500 were Jewish boys from private secondary schools in Haifa, from families who took their infants to welfare centres and to physicians, and who gave vitamin $D$ to their infants. The other 500 were non-Jewish boys from 2 Druse villages and a Haifa Arab school, from families whose children had not received infant welfare services during infancy.

No difference in the incidence of orthopaedic deformities in the 2 groups was found. This casts doubt on the relative importance of prescribing vitamin $\mathbf{D}$ or the value of infant welfare services in this country. It is probable that rickets in Israel rarely leaves permanent sequelae'.

The authors took the view that the orthopaedic deformities observed were essentially a 'carry over' from infant rickets. But since we have found that bowing in schoolchildren increases with age, their conclusion on the lack of effectiveness of vitamin D supplementation in infancy requires re-examination.

\section{The bearing of the pubertal growth spurt on the prevalence of leg abnormalities}

What causes this increase in bowing in apparently healthy children? The change appears to be associated with the growth spurt, which forms part of the complex of changes that occur at puberty (Tobias, 1972). In our studies most groups of girls of 12 years had higher prevalences of bowing than boys of the same age. Part of the explanation may be in the earlier growth spurt experienced by girls (10-13 years) compared with boys (12-15 years) (Marshall and Tanner, 1969, 1970) and the increased metabolic need of vitamin D during this period.

In her excellent study, Round (1973) showed that a serum alkaline phosphatase flare paralleled the growth spurt, and fell to reach adult levels by the end of the fifteenth year in girls, but not until $18+$ years in boys. 'In both sexes this fall is due to a reduction in bone phosphatase levels'. In discussing this finding, Stamp and Round (1973) concluded 'that the alkaline phosphatase flare is a normal physiological event at puberty'. If this is the case, may not the changing shape of the lower limbs be physiological? It is conceivable that many of the changes, particularly those in the milder categories, lie within the normal physiological range.

Clearly, the high prevalance of leg abnormalities in the outwardly healthy children studied is not due to a primary deficiency of the vitamin. Of other explanations, a plausible one is that a metabolic block, inhibition, or retardation occurs at some point in the synthetic pathway of cholecalciferol (vitamin $\mathrm{D}_{3}$ ) to its active polar metabolite, 1,25-dihydroxycholecalciferol (1,25-DHCC). Such a block, implying an increased need already demonstrated by Round (1973), could cause a secondary vitamin D-deficiency during this period of active growth. Furthermore, the block, already postulated as 
arising concurrently with an increased requirement, may occur independently of increased physiological need with the same net result, that of a deficiency of vitamin $\mathrm{D}$. This might explain the increased tendency of lower limbs to bend outward (bowing) or inward (knock knee) according to type and degree of stress, due presumably to a softening of rapidly growing bone. Since overweight children have a greater prevalence of knock knee than others, this phenomenon could be attributed to an increased body mass exerting greater pressure on mass-bearing bones. Since observations indicated that not all children experienced an increase in bowing with age, nor of knock knee with overweight, this presumably indicates individual differences in requirement of either vitamin $\mathrm{D}$, or some other related metabolite.

The plasma level of 25-hydroxycholecalciferol (25-HCC), the major circulating metabolite of vitamin $\mathrm{D}$, has recently been regarded as the most accurate available biochemical index of vitamin D status (Stamp and Round, 1973). It would therefore be particularly illuminating to determine levels of this substance in the plasma of contrasting groups, particularly over the pubertal growth spurt. In a recent article on raised levels of 25-HCC found during summer months in Asians and Whites in Britain, Gupta, Round and Stamp (1974) have emphasized 'the importance of summer in the maintenance of vitamin-D nutrition and the prevention of rickets'. This would have to be borne in mind when collecting samples for the above analyses. A further step in the synthetic pathway of vitamin $D$ is from 25-HCC to its active metabolite 1,25-DHCC (DeLuca, 1971, 1973; Norman, 1971; Kodicek, 1974). This new hormone, which operates in gut and bone, and is metabolized in kidney, has only been measured in experimental studies. This active metabolite would be the one most desirable to measure, in order to establish the true vitamin D status in contrasting groups.

Further approaches would be to attempt to correlate leg abnormalities with individual vitamin D status of schoolchildren during their pubertal growth spurt, also to carry out prospective studies of the type already undertaken, from birth to adolescence. At present, the complicated techniques for the determination of 25-HCC and 1,25-DHCC in plasma preclude their use in the large scale epidemiological studies envisaged. Once simpler techniques become available, such studies could be undertaken with the hope of clarifying the present uncertain aetiology of leg abnormalities in schoolchildren.

\section{Acknowledgments}

We are grateful to Miss M. Wadvalla, Mrs B. F. Walker, Mrs A. Woolford, and Miss L. Daya for their assistance; also to the many school Principals, members of Staff and all pupils who so willingly participated in this study.

\section{References}

Ames Company (1970) Ames/BMI Blood Analyser Technical Manual. Berkeley, California.

ARneIL, G.C. (1967) Dietary study of 4365 Scottish infants1965. Scottish Health Services Studies, No. 6. Scottish Home and Health Department.

Avioli, L.V. \& Haddad, J.G. (1973) Vitamin D: Current concepts. Metabolism, 22, 507.

BarnetT, E. \& Nordin, B.E.C. (1960) The radiological diagnosis of osteoporosis-A new approach. Clinical Radiology, 11, 166.

CRADDOCL, D. (1969) Obesity and its Management, p. 7. Livingstone: London.

Dancaster, C.P. \& JACKson, W.P.U. (1962) Studies in rickets in the Cape Peninsula. South African Medical Journal, 36, 364.

DeluCA, H.F. (1971) Role of kidney tissue in metabolism of vitamin D. New England Journal of Medicine, 284, 554.

DeluCA, H.F. (1973) The kidney as an endocrine organ for the production of 1,25-Dihydroxyvitamin $\mathrm{D}_{3}$, a calciummobilizing hormone. New England Journal of Medicine, 289, 359.

Feldman, N. (1950) Infantile rickets: Its occurrence in nonEuropeans in Johannesburg. South African Medical Journal, 24, 1053.

Ford, J.A., Colhoun, E.M., McIntosh, W.B. \& Dunnigan, M.G. (1972) Rickets and osteomalacia in the Glasgow Pakistani Community. 1961-71. British Medical Journal, ii, 677.

Fox, F.W. (1966) Studies on the Chemical Composition of Foods commonly used in Southern Africa. South African Institute for Medical Research: Johannesburg.

Garti, J. \& Winter, S. (1964) Permanent skeletal deformities following infantile rickets. Journal of the Medical Association of Israel, 56, 216.

Gitelman, H.J. (1967) An improved automated procedure for the determination of calcium in biological specimens. Analytical Biochemistry, 18, 521.

Glisson, F. (1650) De Rachitide. London. Cited by Ferguson, M.A. \& Findlay, L. (1918). Medical Research Committee, Special Report Series No. 20. Sir Joseph Calston \& Sons Ltd: London.

Gupta, M.M., Round, J.M. \& Stamp, T.C.B. (1974) Spontaneous cure of vitamin-D deficiency in Asians during summer in Britain. Lancet, i, 586.

Holt, J.F., Latourette, H.B., Watson, E.H. \& Arbor, A. (1954) Physiological bowing of the legs in young children. Journal of the American Medical Association, 154, 390.

HuRsT, R.O. (1967) A simplified approach to the use of determinants and calculation of rate equations for complex enzyme systems. Canadian Journal of Biochemistry, 45, 2015.

JACKSON, R.L. \& KELLY, H. (1945) Growth charts for use in pediatric practice. Journal of Pediatrics, 27, 215.

Joffe, B.I., Hackeng, W.H.L., Seftel, H.C. \& HaRtdegan, R. (1972) Parathyroid-hormone concentrations in nutritional rickets. Clinical Science, 42, 113.

KodiceK, E. (1974) The story of vitamin D. Lancet, i, 325. Marshall, W.A. \& TANNer, J.M. (1969) Variations in the pattern of pubertal changes in girls. Archives of Diseases in Childhood, 44, 291.

Marshall, W.A. \& TAnner, J.M. (1970) Variations in the pattern of pubertal changes in boys. Archives of Diseases in Childhood, 45, 13.

McLaughlin, M. (1973) Ultraviolet deprivation. Lancet, i, 1386. 
NoRman, A.W. (1971) Evidence for a new kidney-produced hormone, 1,25-dihydroxycholecalciferol, the proposed biologically active form of vitamin D. American Journal of Clinical Nutrition, 24, 1346.

PARKer, R.W. (1888) In: Discussion. II. The surgical treatment of rickets. British Medical Journal, ii, 1151.

RichardS, I.D.G., Sweet, E.M. \& ARneIL, G.C. (1968) Infantile rickets persists in Glasgow. Lancet, $\mathbf{i}, 803$.

Richardson, B.D. \& Walker, A.R.P. (1973) Prevalence of bowing and knock-knee in South African schoolchildren. Lancet, ii, 377.

Richardson, B.D. \& Walker, A.R.P. (1974) Bowlegs, knock-knees and vitamin $D$ status in schoolchildren. New England Journal of Medicine, 290, 346.

RoberTSON, I. (1969) Survey of clinical rickets in the infant population in Cape Town 1967-1968. South African Medical Journal, 43, 1072.

Round, J.M. (1973) Plasma calcium, magnesium, phosphorus, and alkaline phosphatase levels in normal British schoolchildren. British Medical Journal, iii, 137.
Sherman, M. (1960) Physiologic bowing of the legs. Southern Medical Journal, 53, 830.

Stamp, T.C.B. \& Round, J.M. (1973) Serum alkaline phosphatase and rickets. British Medical Journal, ii, 551.

TAITZ, L.S. (1962) The role of the parathyroid glands in vitamin $\mathrm{D}$ deficiency rickets. Doctoral thesis, University of the Witwatersrand, Johannesburg.

TAITZ, L.S. \& DE LACY, C.D. (1962) Parathyroid function in vitamin D deficiency rickets. Pediatrics, 30, 875 .

ToBIAS, P.V. (1972) Growth and stature in Southern African populations. In: The Human Biology of Environmental Change, p. 96. Proceedings of a Conterence held in Blantyre, Malawi. International Biological Programme: London.

Weather Bureau, Department of Transport (1968) Report on meteorological data of the year 1967. Government Printer: Republic of South Africa, Pretoria.

Weiner, J.S., Harrison, G.A., Singer, R., HARRIS, R. \& JOPP, W. (1964) Skin colour in Southern Africa. Human Biology, 36, 294. 